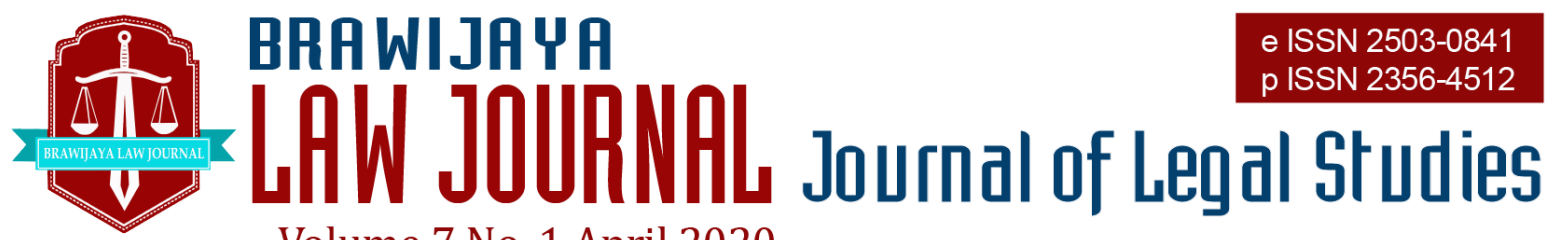

Volume 7 No. 1 April 2020

Nationally Accredited No. 30/E/KPT/2018 Dated 24th October 2018

This work is licensed under a Creative Commons Attribution-NonCommercial 4.0 International License

\title{
Examining on Indonesian Legal Challenges for Future Transnational Healthcare Service
}

\author{
Febrian Indar Surya Kusuma ${ }^{a}$ Sapto Hermawan ${ }^{b}$ \\ ${ }^{a}$ Faculty of Law, University of Sebelas Maret \\ Surakarta, Central Java, Indonesia, 57126 \\ Email: febriank28@gmail.com \\ ${ }^{\mathbf{b}}$ Faculty of Law, University of Sebelas Maret \\ Surakarta, Central Java, Indonesia, 57126 \\ Email: Saptohermawan_fh@staff.uns.ac.id
}

Submitted : 2020-02-29 | Accepted : 2020-04-13

\begin{abstract}
Facing the fourth industrial revolution, the state must strengthen its role to protect its citizens as a part of its efforts to provide social security. Indonesia as a nation also have to face this challenge, especially on the ability to provide healthcare and medication for their citizen neither they lived in the country nor stay overseas. This kind of issue has to be our concern because of our current situation in the globalization era force us to eliminate the national border and start to design transnational services to fulfill our basic needs. Therefore, this paper will conduct research that focuses on the healthcare and medication services in the South East Asia, especially a comparison between Malaysia and Indonesia's government. Furthermore, this study will also give a brief preview of the 4.0 industrial revolution that brings the shifting of a new era for fulfilling a necessary healthcare service by using transnational big data. Through a social justice perspective and sociological law approach, the researcher uses social security theory that will lead us to reach the concept of the welfare state. This comparison will give us a larger image to see Indonesian government legal challenges and opportunities to provide a new form of healthcare services.
\end{abstract}

Keywords: $\quad$ healthcare service; social security; transnational services.

\section{INTRODUCTION}

As a part of global society, we live in a specific mechanism that makes us follow any shift of an era. In 1760, the beginning of the industrial revolution, introducing the use of steam engines and at the beginning of the 20th century, we can make a mass production using electricity. Afterward, the Industrial
Revolution, followed by the digital revolution that uses the computer in 1960 and introducing the internet in 1990. People begin to adapt to the extensive access to information that no longer restricted by territory, or "tools such as laptop, desktops and tablet as in previous decades"1. This shift

1 Huraizah Zakaria, et.al, 'IoT Security Risk Management Model for Secured Practice in 
of an era, ascertain bring along the shift of socio-economic life and policy to society.

Nowadays, people almost have no limit to access any variety of information at any time and any place. The advanced technology of mobile devices makes us see the world differently. Information disclosure is a sign of a digital revolution, which also supported by the sensor evolution that processes passive data gathering with meaningful interpretation, the advance of the digital revolution begins to enter the era of the 4.0 industrial revolution. The term of 4.0 industrial revolutions it is coined in Germany at the Hannover Fair (2011). This term refers to the system integration based on cloud computing using internet things that can process Big data resources. ${ }^{2}$.

The 4.0 industrial revolutions emphasize the use of the "Internet of Things" that also develop the Artificial Intelligence, widen the fusion of technology in the physical, digital, and biological world. According to Klaus Schwab $(2016)^{3}$, this shift will focus on three fields, velocity, breadth and depth, system impact. Velocity adjusting for making interconnectivity across sectors and borders in the world where we live in, Breadth and depth will bring the change from "what to How" and who we are in the field of economy, businesses, society, economics and individually. And last but not least, this 4.0 industrial revolution will give an impact on the system that already exists in the world. This era will transform the whole economy, societies, countries, companies, and industrial systems.

How we see the advance changing of the technology will affect how we see the world, we have choices on how we will use it. Positively, the industrial revolution will affect and will be affected by countries,

\footnotetext{
S.I. Tay, et al, 'An Overview of Industry 4.0: Definition, Components, and Government Initiatives' (2018) 10(14-Special Issue) Journal of advanced Research in Dynamical and Control System,

<https://www.researchgate.net/publication/33244 0369_An_Overview_of_Industry_40_Definition_ Components_and_Government_Initiatives> accessed December 20, 2019

3 Klaus Schwab, The Fourth Industrial Revolution, (World Economic Forum, Switzerland, 2016)
}

economies, industries, and people, so that the reason why we need to build the awareness of the multi-stakeholder to notice this issue. This transformation will bring a numerous shifts in an immeasurable way if we can manage to have cooperation across academic, social, political, national and industry boundaries. Of course, it will also have linkages with the government's policy, and country statutory.

As the 4.0 industrial revolution have a more extensive scope, we need to see this phenomenon as an opportunity to extend the government policy that can bring social justice to society. In the West Country that already has established economic growth; the government has a significant role to provide social security for its citizens. ${ }^{4}$ With all the respect, social justice in the South East Asia region needs improvement, more specifically, in the field of social security that provides healthcare services as human basic needs. For the developing countries, the government will have more attention in the economic sector rather than social policy, and it's a typical case in Southeast Asia countries. Moreover, the healthcare in some developing countries are "characterised by a large private, sometimes informal, provider sector due to the inadequacy of state healthcare and the financing is often not enough"

Limitations on the access of resources become one of the most important factors that give an influence on the government's policy direction. The social policy usually takes the most significant part of government expenditure. Therefore, in a developing country, the government will give less attention to that sector ${ }^{6}$. Some of Asia's government also rejected the idea of 'welfare state,' but they don't realize that there is so many social securities policy that they have

4 Robert East, Social Security Law, Macmillan Press Ltd, London, 1999, p. 1

5 Chee Heng Leng, 'Ownership, Control, and Contention: Challenges for the Future of Healthcare in Malaysia', (2008) Journal Social Science \& Medicine, Vol 66, p. 2145-2156.

6 M. Ramesh, et all, Welfare capitalism in Southeast Asia: Social Security, Health and Education Policies (ST. Martin's Press, INC, America, 2000), 3. 
to support the bureaucrats. With the fact that the government still have a low level of awareness related to social security and the resources' factor that also exist behind that issue, therefore this phenomenon has to be our concern.

Focusing on South East Asia social security cases, the research will try to observe Indonesia's social security policy. As a part of the South East Asia country that has a dynamic economic growth, an archipelago state, and have a significantly different social security scheme, researchers argue that it will be interesting to learn from this peculiarity. Related to Law Number 40 the year 2004 about National Social Security System, the government of Indonesia has a responsibility to divert individual risk to be a national responsibility to fulfill life subsistence under the condition of sickness, work accidents, unemployment, aging, and pension. This constitution indicates that Indonesia already has a statute that regulates the government's responsibility to provide social security.

Through BPJS Kesehatan and BPJS Ketenagakerjaan $^{7}$, Indonesia's government promotes the development of social security services. Using the 'gotong-royong' principle, BPJS has a different model of funding compare to another health insurance. The central financial source came from BPJS Participant's contribution. Since 2011, BPJS already cover the healthcare service for Indonesian people that join as BPJS members. Although it almost 8 years of BPJS, but there is so much limitedness that still occurs and needs to analyze their possibility to gain more extensive access and scope to give a social justice for all of the Indonesian citizens.

This study will conduct research that focuses on the legal challenges and opportunities that the Indonesian government might have to give social justice for all of the

7 BPJS (Badan Penyelenggara Jaminan Sosial) is a department that was formed by the Indonesian Government to provide social security for the citizen. BPJS Kesehatan is a social security program that available for all the Indonesian citizen, while BPJS Ketenagakerjaan is a social security program for the worker in Indonesia, including foreign worker.

8 Raymond R. Tjandrawinata, 'Industri 4.0: revolusi abad ini dan pengaruhnya pada bidang citizens of Indonesia. In other words, we will also have to see the probability of BPJS become a transnational healthcare service provider for Indonesia citizens and give a contribution to regional healthcare and medication big data. These opportunities might be the social security improvement that takes advantage of the 4.0 industrial revolution era. As the researcher mention above, the improvement of social policy will take a lot of country's expenditure, so we have to maintain the ability that we might have from the 4.0 industrial revolution era to make an improvement that has a minimum cost.

This paper will discuss two main research questions. Firstly, in comparison with other Southeast Asia countries member, we will see how do Malaysia and Indonesia provide social security in the field of healthcare services? Secondly, this research will also discuss how does the Indonesian legal system face the shift of the 4.0 industrial revolution, and what do the opportunities and challenges to provide new forms of transnational healthcare and medication services? These two questions will give us an illustration of Indonesia's future social security services if we can manage to take advantage of the 4.0 industrial revolution.

Studying about legal challenges and opportunities in the providing transnational social security field that related to the 4.0 industrial revolution in Indonesia is still low, since the beginning of the 4.0 industrial revolution. Research has been conducted before in the science field that talks about how 4.0 industrial revolution might have an impact on medication in Indonesia like the working paper that already published by Dexa Medica Group in $2016^{8}$, STIKES Siti Hajar Medan in 2019, ${ }^{9}$ and the recent

kesehatan dan biologi', (Research, Dexa Medica Group, 2016),

$<$ https://www.researchgate.net/publication/29369

5551_Industri_40_revolusi_industri_abad_ini_da n_pengaruhnya_pada_bidang_kesehatan_dan_bio teknologi> Accessed December 20, 2019

9 Lagut Sutandra, et al, 'Analisis Layanan Teknologi Komunikasi Klinik Fisioterapi Siti Hajar Era Revolusi Industri 4.0’'(2019) 3(1) Jurnal Sistem Informasi 
presentation by Universitas Gadjah Mada in Rakerkesnas 2019. ${ }^{10}$ The presentation by Anis Fuad in Rakerkesnas has similarities with this research, but the difference lies in the main issue. This study will have more extensive analytical in the field of legal challenges and opportunities to provide a wider scope of healthcare service for Indonesia's citizens, whether they live within the country or stay overseas.

It's an urge to discuss future social security policy in Indonesia because the 4.0 industrial revolution has a peculiarity in the velocity, breadth, and depth, as the researcher already mention above. We need to realize that the effect of globalization and the shift of the industrial revolution requires high mobility that no longer limited to a country as a territory. Along with the reality that Indonesia has a lot of citizens living overseas, either they working or studying. The government of Indonesia has to realize that they have the responsibility to ensure that every Indonesian people can get the same access to basic needs in the name of social justice.

Time efficiency is also crucial to improve medical services. We need to ascertain that our state statutory can be more adaptive to the current situation and global standard. By using big data and artificial intelligence, we can have more chances to have individual medical records at any stage that can be accessed by our mobile devices or our BPJS member card. This record will also be used by the government to keep an eye from the health care provider who collaborated with the government. Furthermore, transnational healthcare services can use to make an integration of medical support in the region.

\section{LEGAL MATERIALS AND METHODS}

This research will use qualitative research based on empirical and normative studies to analyze data. It also will take the scope of South East Asia, especially

<http://jurnal.uinsu.ac.id/index.php/query/article/

$>$ Accessed December 20, 2019.
Indonesia, and Malaysia as a comparison. With the theoretical view about social security that conduct by Mukul G. Asher, the researcher will analyze how the Indonesia, and Malaysia, Government try to provide social security in the field of healthcare service.

\section{RESULT AND DISCUSSION}

The transformation of the industrial era also followed by the shift of the individual preference to make a subsistence. Before the industrialization era, people tend to selfemployment, and after that, industrialization brings the trend of wage employment. This shift, also brings the shifting of the risk that they have to face. The employments have to face the risk of unemployment, sickness, industrial injury, etc, consequently, to overcome the individual risk, the government needs to maintain the formal social security. According to Rimlinger, the social security program also has a benefit to promote preparation for industrial employment and commitment to work. ${ }^{11}$

The commitment of the government to ensure their citizens' income and welfare is needed. To gain the welfare state, the citizens also have to be protected from any risk that might occur. Therefore, in this chapter, the researcher will give a brief introduction to the social security comparison provided by Indonesia's government and Malaysia's government. Furthermore, we can see the main idea of the 4.0 industrial revolution and the legal challenges and opportunities that Indonesia's government might have in the future to provide social justice in the field of social security programs, especially on healthcare services.

\section{Social Security and Healthcare Services in Indonesia and Malaysia}

As a part of ASEAN members and also known as the member of ASEAN 5, Malaysia and Indonesia share the same socio and cultural conditions. In some ASEAN countries, the social security program is not a

10 Anis Fuad, 'Inovasi dan Pemanfaatan teknologi Digital Bidang Kesehatan', (Presentation, Rakerkesnas, Tangerang, 12 February 2019).

11 M. Ramesh, et all, above n 6, 5. 
government main program that is a usual condition. The government has more concern in the field of the economic sector because we still have to increase economic growth to gain more steady economic conditions. But this fact doesn't mean that there is social security at all.

It has said by Mukul G. Asher through his book that the central purpose of social security is preventing a significant and abrupt fall of living standard because of retirement, death, disability, occupational injury or disease, or unemployment. ${ }^{12}$ These issues might be a common cause of poverty. Therefore, the government needs to make such a social security scheme for its citizens to alleviate the risk that might be caused by these issues. For countries that also still have an issue to stabilize their national economic growth, it might be hard, because we need to know that social security will always take a lot of national expenditure. Not only affected by national economic stability, the capability of the government to give such social security for it citizen will also be affected by other factors such as political condition, geographical situation, socio-cultural, etc.

Since the very beginning, there is no single social security scheme that can be fit for all countries. Including countries that already try to provide social security for its citizens, at some point, the government might give a different scheme for a different situation or change the social security scheme overall. Abdul A. Wahab stated that "Government funding for health care mainly include capitals from government financial plan and social security schemes" 13 . Adjustment needs to be made by the government if the social dynamic and global shift might give a negative impact on the citizen that receives the benefit from these social security programs.

\footnotetext{
Ibid. M. Ramesh, et all, 30

13 Abdul Azeez Oluwanisola Abdul Wahab, Zurina Kafeli, 'Projecting a Long Term Expenditure Growth in Healthcare Service: A Literature Review', (2016) 37 Procedia Economics and Finance, P. 152-157.

14 Donald S. Shepard, wt al, 'Health Care Reform Initiatives in Malaysia', (Report, Schneider Institute for Health Policy, 2002), 11
}

According to Mukul G. Asher's books, "Welfare Capitalism in Southeast Asia," in the very beginning, Indonesia has a social security program for private-sector worker since 1920, but this pension scheme didn't have a long term benefit and only can give security system for a few numbers of a private worker. Afterward, the Indonesian government made two social security programs that separate it for the private worker and public sector worker. The private worker in Indonesia got social security program under Jamsostek (Jaminan Sosial Tenaga Kerja). Since 1992, through Jamsostek, the employer sponsors a pension fund for their worker, while for the public sector worker, there are 2 (two) different schemes for the social security program. First, they will get TASPEN (Tabungan dan Asuransi Pegawai Negeri) and they will also get pension funds. TASPEN will only give the pension fund once when they reach the pension age, while on the other hand, there will also a pension scheme that was given to the retired workers every month. The Public sector worker takes a lot of government expenditure. Now, the government of Indonesia makes a new social security scheme that covers all of the public and private sectors. Under Badan Penyelenggara Jaminan Sosial (BPJS), the government of Indonesia tries to cover the entire previous Social security scheme. They just divided into two different kinds of BPJS, BPJS Kesehatan, and BPJS Ketenagakerjaan.

Malaysia also has an almost similar social security scheme with Indonesia. There are few types of pension scheme in Malaysia such as the Employee Provident Fund $(E P F)^{14}$ that was established in October $1951^{15}$; Employment Injury and Invalidity Benefits Scheme; and Old Age Pension Scheme for Civil Service and Military, the Teachers Provident Fund (TPF), the

\footnotetext{
$<$ https://www.who.int/health_financing/document s/malaysia-reform-initiatives.pdf $>$

15 Siti Sheikh Hussin, et al, Employee's Provident Funds Of Singapore, Malaysia, India and Sri Lanka: A Comparative Study, in Gautama Mitra(ed), Asset and Liability Management Handbook, (Palgrave Macmillan, New York, 2011), 190.
} 
Malaysian Estates Staff Provident Fund and a handful of statutory and private provident funds. The interest of this scheme is different; depend on the group of the worker. People's group that working in the public sector, receiving the best benefit of this scheme. ${ }^{16}$ These days, the Malaysian government try to make a new scheme of social security services, but there is a delay because of this scheme will cost higher than before and need more than $10 \%$ of Malaysian people's monthly income to cover it. ${ }^{17}$

As we can see, both Indonesia and Malaysia still seek the most fitting social security scheme. The main reason that makes the government need to adjust its social security scheme is its ability to find the most appropriate funding scheme, if the government wants to take over all of the pension funding and healthcare service during their working age, it will take a higher cost, and take a large amount of the national expenditure, on the other hand, if the funding came from the worker only, it will be difficult. These challenges need a contextual solution because each country has its own political, socio-cultural, and economic context that might be different from other countries.

\section{Indonesian Legal System Challenges and Opportunities in 4.0 Industrial Revolution Era.}

The 4.0 Industrial Revolution is the new era that coined at the Hannover fair in Germany (2011). This era begins with the adaptation of the Cyber-Physical System and integrated with the Internet of Things (IoT). As can be seen in Figure 1, if the previous digital revolution (Industry 3.0) only emphasizes the use of computerization, automation, and using electronic devices, this era constrains the utilization of the digital device with more complexity. Using the Internet of Things, Simulation and
Autonomous Robots, this era needs to develop Artificial Intelligence (AI) that processing Big Data.

Velocity becomes the main achievement that needs to attain. The use of AI can give more accuracy, cost efficiency, and accelerate the time taken for processing the data. Using the cloud to save big data can reduce the cost of storage, but it also costs privacy and data safety. One of the challenges that might be faced by the 4.0 industrial revolution is the ability to maintain the highest level of cybersecurity. Once the Big Data exists, the artificial intelligence system can process it purposively at any time and any place. This will bring more advantages to the government with the widearea and widespread citizen.

To take advantage of this era, many sectors try to imagine how this kind of technology can be used, including in the social, economic, politics, and science. The fusion across sectors and countries can increase the benefit of this new era. With the focus on this research that aims to give social justice in the field of social security system to conduct a new form of transnational healthcare services that might be adopted by the Indonesian government, there must be collaboration multi-stakeholders and multisectoral that work together.

Since 1998, there is a shift in the Indonesian government ruling system. The reformation that begins the transformation from state-centered to people-centered the government of Indonesia tries to make a formal social security system that can protect all of the citizens. It takes almost 15 years to finish the entire legal basis that needs to do before the new social security program possibly implemented. One of the main focuses on this social security system gives healthcare services under Badan Penyelenggara Jaminan Sosial (BPJS).
16 Lee Poh Onn, 'What Lies Ahead for Malaysian Healthcare?', (Working Paper, ISEAS Economic Working Paper, 2015), p.6
17 David K.L Quek. The Malaysian healthcare system: A review, <https://www.researchgate.net/publication/23740 9933> accessed December 20, 2019 
Figure 1. The Industrial Revolution ${ }^{18}$

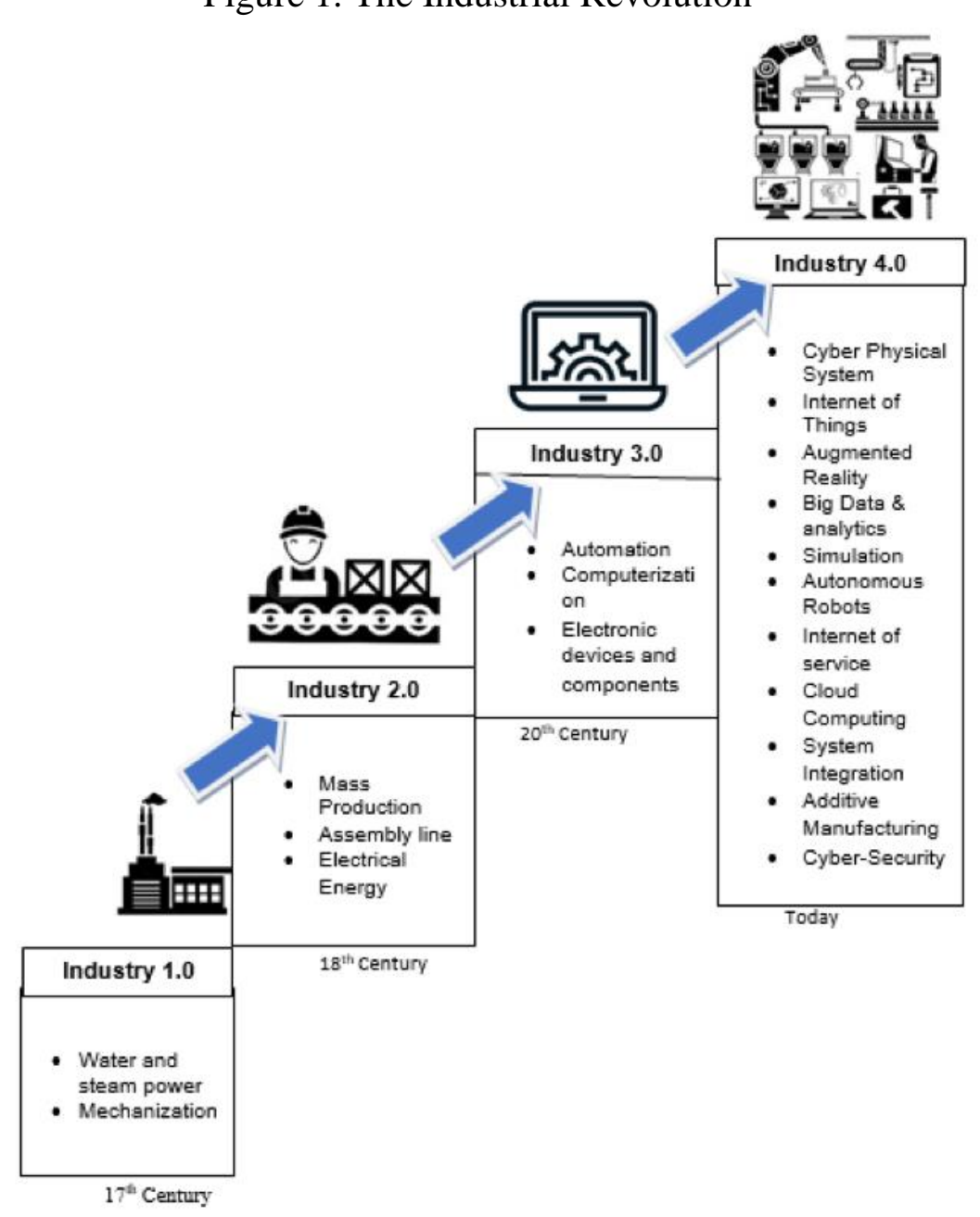

According to the 1945 constitution of the Republic of Indonesia article $28 \mathrm{H}$ paragraph (3) and Article 34 paragraph (2), it states that Indonesian people have a right to get social security the government has a responsibility to make a social security system that can protect all of the citizen, especially they who can not afford to have a decent life. As Indonesia juridical foundation, that constitution clearly and decisively mentions the government of Indonesia to make social security system for its entire citizen. According to Law Number 12, the year 2006 about the Nationality of the Republic of Indonesia, the Indonesian citizen is everyone who ratified by the constitution or an origin Indonesian.

Derivative regulation for that constitution legislates the law about Sistem Jaminan Sosial Nasional or National Social Security System. The regulation about the
Indonesian Social security System states that this program has intended for all Indonesian citizens. In this article, the government did not mention that only citizens who lived within the country that has a right to get a social security program. Of course, it may explain that the government must give protection, although their citizen lives overseas.

Furthermore, Law Number 24 the year 2011 about the National Agency of Social Security System Organizer (Badan Penyelenggara Jaminan Sosial Nasional) or known as BPJS's Law set about the establishment of BPJS Kesehatan and BPJS Ketenagakerjaan. BPJS Kesehatan is a social security program that applies to all Indonesian citizens and foreign workers that already work in Indonesia for more than 6 months. While BPJS Ketenagakerjaan is a social security program that intended for any

18 S.I. Tay et al, above n 1, p. 1389.

102 | Kusuma, Hermawan - Examining on Indonesian Legal Challenges for... 
Indonesian worker and foreign worker that already work in Indonesia for more than 6 months, that has been designed for covering industrial injury, life insurance, pension plan.

In the BPJS' regulations, nine principles must be held: "kegotongroyongan" is the first one that manages the contribution on the financial funding; BPJS members contribute following their wages. This principle enables BPJS members to provide subsidies for each other to cover the medical cost. The second principle is non-profit, this principle assigns BPJS to use the contribution fund to give the most significant benefit to all of BPJS member, and the third principle in BPJS is an openness to simplify the access of information. The fourth principle is prudent BPJS has to manage the fund wisely, careful, secure, and orderly.

The fifth principle is accountability; BPJS has a responsibility to be responsible for financial management. The sixth principle is the probability that enables the BPJS member to continue their medication although they move to another city (within the country) or change their job. The seventh principle is mandatory membership that requires all of the Indonesian citizens to be a BPJS member step by step. The eighth principle is a trust fund, the contribution funding is just a deposit, and the last principle is the fund management result that must do to fulfill the needs of the member. ${ }^{19}$

According to this principle, there is some deficiency. In the first article of Law Number 40 the year 2004, we can see that the government must ensure that they give protection to all Indonesia citizens as a part of social justice. However, in the same constitution, in article 4 that mentions about BPJS principle, BPJS only continues to cover the BPJS member that moves within this country. In other words, the government no longer can give social security if their citizen going overseas. Furthermore, Law Number 17 , the year 2007, states that one of the long terms national targeted equitable development and provides the same access to social services for all the Indonesian people.

19 SJSN' Law, article 4
This issue can be the legal challenges that have to be faced by the government to bring social justice for all.

As the researcher already mention before, the opportunities to take advantage of 4.0 industrial revolutions is the ability to adapt. Our legal system can adapt to this shift of an era. Indonesia's government has the same direction to bring along the 4.0 industrial revolution across sectors to make a fast improvement of social services at the grass-root level. Including the task to take the 4.0 industrial revolution, the government policy has already opened up the possibilities to develop mobile device apps, significant data resources, and telemedicine that can reach a more extended scope.

Although the development of this application still in the very first step, we can see that Indonesia has a supportive public policy related to the 4.0 industrial revolution. As it mentions in the President Decree Number 82 the year 2018 about Health Insurance Article 65, if there is no medical services provider, the government can make a mobile healthcare service, healthcare services based on the telemedicine or other medical services that might be appointed by the ministry of health. Furthermore, the health ministry set a rule about telemedicine. ${ }^{20}$

For the healthcare services' innovation related to the 4.0 industrial revolution, the ministry of health with BPJS makes an application that coined Mobile JKN. This application is applicable to access your personal information based on BPJS membership. Figure 2 shows the display of mobile JKN. Some button still cannot be accessed, but we can see that this application is quite complete in the future. To make this application, the ministry of health working together with the ministry of civil registration, because this account has some button that will linkage with other(s) accounts, that exists in the same family card.
20 Minister of Health Regulation Number 20 year 2019 about Organizing Telemedicine Services Between Health Facilities Services. 
Figure 2. Mobile JKN

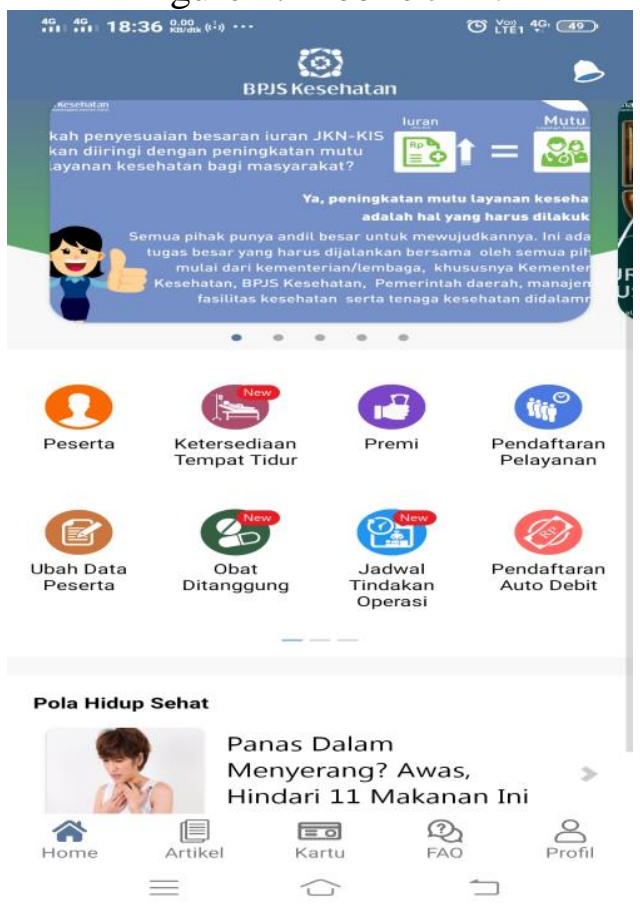

Figure 3. Medical report screening agreement

\begin{tabular}{|c|c|}
\hline \multicolumn{2}{|l|}{ ii fii $17: 12$ : } \\
\hline \multicolumn{2}{|l|}{$\begin{array}{c}192 \\
\text { BPנs Kesehatan }\end{array}$} \\
\hline \multicolumn{2}{|l|}{$\begin{array}{l}\text { Persetujuan Skrining Riwayat } \\
\text { Kesehatan }\end{array}$} \\
\hline \multicolumn{2}{|c|}{$\begin{array}{l}\text { Saya dengan sadar dan atas keinginan sendiri } \\
\text { bersedia menerima pelayanan Skrining Riwayat } \\
\text { Kesehatan atas diri sendiri. Selanjutnya saya } \\
\text { bersedia data riwayat kesehatan diri saya } \\
\text { dipergunakan oleh Dokter dan BPJS Kesehatan } \\
\text { dalam rangka analisa kesehatan BPJS } \\
\text { Kesehatan. }\end{array}$} \\
\hline \multicolumn{2}{|l|}{$\begin{array}{l}\text { Data yang saya isi merupakan data yang } \\
\text { sebenarnya. }\end{array}$} \\
\hline \multicolumn{2}{|c|}{$\begin{array}{l}\text { Pelayanan skrining riwayat kesehatan dapat } \\
\text { diperoleh setiap setahun sekali. }\end{array}$} \\
\hline Setuju & TIdak \\
\hline
\end{tabular}

Figure 4. Medical Behavior question

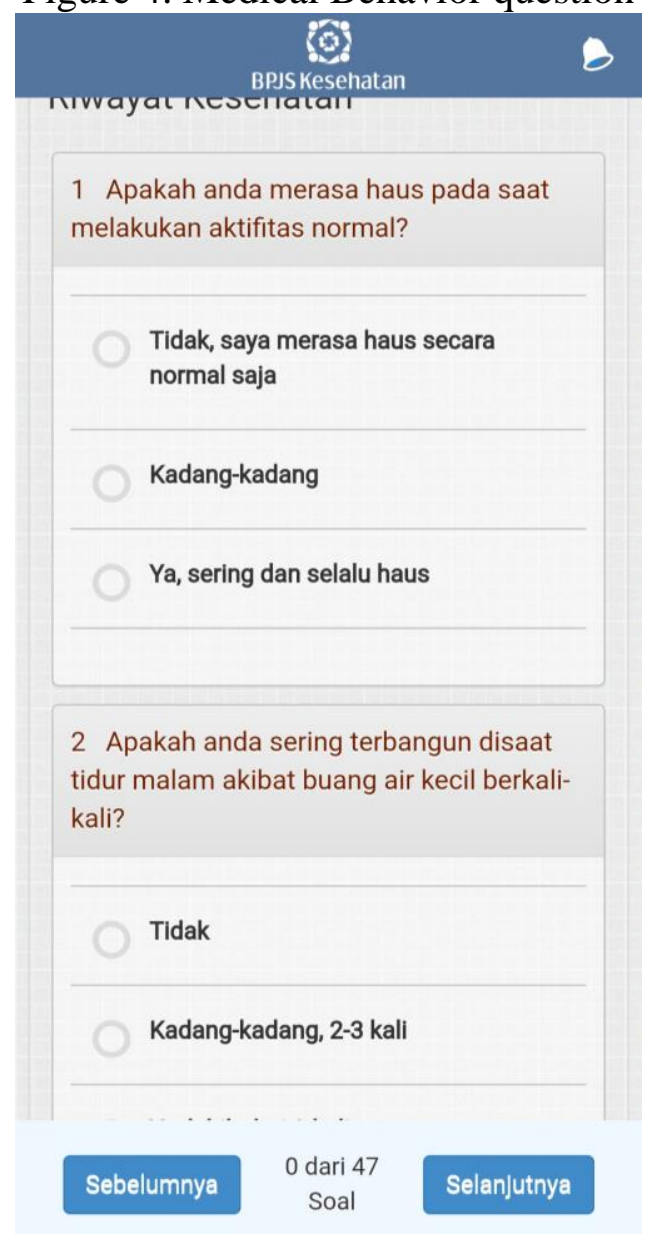

With this application, as we can see in figure 3 and figure 4 , the ministry of health also wants to conduct the individual medical record. We also can find the button to fill essential medical records and our medical behavior. If we choose to fill this database, the ministry will use our data to make an analytical medical report, based on our data. This kind of data can be a great start to make a big data center that applicable to track our medical report, the healthcare service that we receive from the social security program, and this will be a data that might be able to be accessed by the medical service provider in the emergency. As we know, that in an emergency, time is very important, if the database of our medical report accessible at the right time, it can help in the critical condition.

Mobile JKN still a new application and the publication about these apps is at the minimum condition. Of course, the government needs to get this app ready before a lot of BPJS members start to use it. But with no socialization about how to use it 
and what the privilege that we might have in the future, it will be difficult to reach a lot amount of individual medical reports and behavior. As we can see in figure 5, there are also challenges because of the gap in using internet access. The government still has to assist fill out the form.

If the individual medical record can achieve by the government this will be a great analytical medical resource. Furthermore, the government of Indonesia can use this Big Data to make regional join research to give more accurate, effective, and efficient prescription or telemedicine for their citizens. The regional medial Big Data analysis that already exists also can develop as a basic telemedicine that will also give social security coverage for Indonesian people that live overseas. Moreover, with the adaptive legal system and improvement in the healthcare services using telemedicine and collaboration within ASEAN countries as a region, Indonesia can develop transnational healthcare services.

Figure 5. Internet access gap ${ }^{21}$

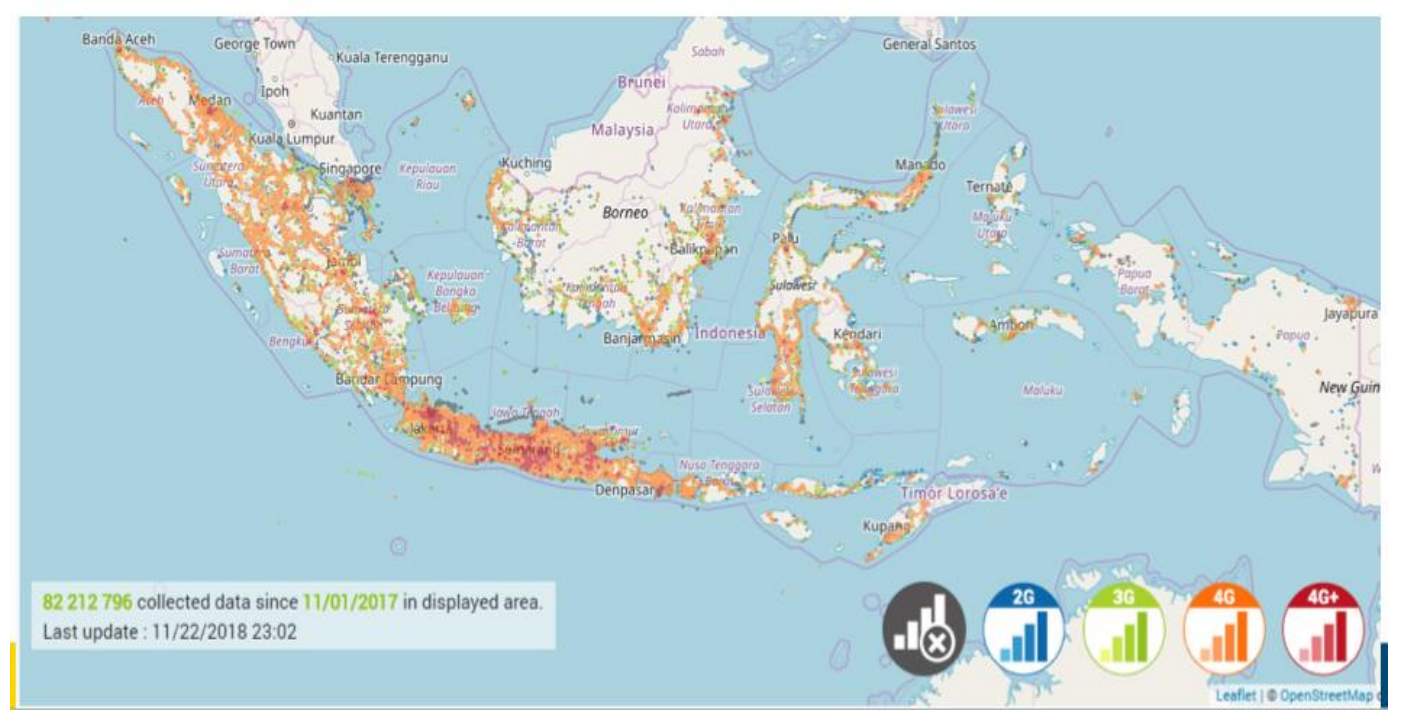

\section{CONCLUSION}

In Southeast Asia, Social Security is not the central concern of the government. The priority of a nation still focuses on the economic sector, rather than social security, this is a usual case because social security always takes most significant part of National expenditure. But recently, the awareness of the social security benefit and importance begins to arise within this region. To make the most suitable social security model, the government of Indonesia and Malaysia still meet with some difficulties. They still focus on how to give a better social security service in the field of healthcare service with the minimum budget and more comprehensive scope.

The 4.0 Industrial Revolution gives us a new point of view about social security services. This new trend forces us to imagine how the future will be if we can take advantage of this era. The fast-changing of the digital revolution to the 4.0 industrial revolution only emphasizes the use of computerization, automation, and using electronic devices, this era constrains the utilization of the digital device with more complexity. Using the Internet of Things Simulation and Autonomous Robots, this era needs to develop Artificial Intelligence (AI) that processing Big Data. To follow the 4.0 Industrial Revolution, the government of Indonesia needs to examine its current legal system. The principal access to enter 4.0 industrial revolutions is the legal system characteristic, whether they can or cannot adapt to the shift and global mechanism. Moreover, the government has to realize that

21 Anis Fuad, Inovasi dan Pemanfaatan teknologi

Digital BidangKesehatan, (Presentation,

Rakerkesnas, Tangerang, 12 February 2019). 
this era requires a multisectoral and multistakeholder collaboration to bring out useful output for their citizen. The ability to adapt to this current era will give more advantage to Indonesia as a country to provide a more comprehensive scope of social security.

The main challenges of Indonesia's legal system are to ensure that the government will give an equal healthcare service (as a part of a social security program) to all of the Indonesian people, whether they live within the country or lived overseas. According to the Indonesian constitution, the government has to provide social justice for all the Indonesian people, but UndangUndang BPJS still only covers Indonesian people that live in the Indonesian territory. With the existence of the 4.0 industrial revolution, the government tries to improve their healthcare service for Indonesian people in the remote area first, by developing mobile $\mathrm{JKN}$ and telemedicine.

Mobile JKN that has been developed by the ministry of health is a great start to enter the 4.0 industrial revolution. Although it will still need a lot of effort to get that app ready, there is no resistance from the Indonesian legal system. The system can adapt to the global mechanism of the 4.0 industrial revolution. This app will also be the principal source of our Big Data in the medical sector. The government later can develop this data to be a good medical analytical resource based on the individual medical report and behavior. This also will improve the healthcare service in a remote area that still doesn't have medical service providers.

Furthermore, developing medical analytic based on this big data can be done across the country within ASEAN as a region. This also will develop the ability to give more effective, efficient, and accurate diagnose. Moreover, not only Indonesian people can use telemedicine facilities, but also Indonesian people that live overseas. This kind of improvement can be a good start to give transnational healthcare services.

\section{REFERENCES}

\section{Books and Report}

East, Robert, Social Security Law. (Macmillan Press LTD, London, 1999)

Hussin, Siti Sheikh, et al, Employee's Provident Funds Of Singapore, Malaysia, India and Sri Lanka: A Comparative Study, in Gautama Mitra(ed), Asset and Liability Management Handbook, (Palgrave Macmillan, New York, 2011).

Mitra, Gautam, Asset and Liability Management Handbook, (Palgrave Macmillan, New York, 2011)

Ramesh, M, et al., Welfare capitalism in Southeast Asia: Social Security, Health and Education Policies (ST. Martin's Press, INC, America, 2000).

Schwab, Klaus, The Fourth Industrial Revolution, (World Economic Forum, Switzerland, 2016)

S. Shepard, Donald, et al, 'Health Care Reform Initiatives in Malaysia', (Report, Schneider Institute for Health Policy, 2002).

\section{Journal}

Jaafar, Safurah, et al, 'Malaysia Health System Review', (2013) 3(1) Health System in Transition.

Keikhosrokiani, Pantea, et al, 'Success Factors in Developing iHeart as a Patient-centric Healthcare System: A multi-group Analysis', (2018) 35 Telematics and Informatics.

Leng, CheeHeng, 'Ownership, Control, and Contention: Challenges for the Future of Healthcare in Malaysia', (2008) Journal Social Science \& Medicine, Vol 66, p. 2145-2156.

Sutandra, Lagut, et al, 'Analisis Layanan Teknologi Komunikasi Klinik Fisioterapi Siti Hajar Era Revolusi Industri 4.0' (2019) 3(1) Jurnal Sistem Informasi.

Tay, SI, et al, 'An Overview of Industry 4.0: Definition, Components, and Government Initiatives' (2018) 10(14Special Issue) Journal of advanced Research in Dynamical and Control System, 
<https://www.researchgate.net/publica tion/332440369_An_Overview_of_In dustry_40_Definition_Components_a nd_Government_Initiatives> accessed December 20, 2019.

Wahab, Abdul Azeez Oluwanisola Abdul, et $a l$, 'Projecting a Long Term Expenditure Growth in Healthcare Service: A Literature Review', (2016) 37 Procedia Economics and Finance, P. 152-157.

Zakaria, Huraizah, et al, 'IoT Security Risk Management Model for Secured Practice in Healthcare Environment' (2019) 161 Procedia Computer Science.

\section{Research/ Paper}

K. L. Quek, David, 'The Malaysian Health Care System: A Review', (Working Paper, Malaysian Medical Association, 2014).

Poh Onn, Lee, 'What Lies Ahead for Malaysian Healthcare?', (Working Paper, ISEAS Economic Working Paper, 2015).

Tjandrawinata, Raymond R., 'Industri 4.0: revolusi abad ini dan pengaruhnya pada bidang kesehatan dan biologi', (Research, Dexa Medica Group, 2016).

\section{Speech}

Fuad, Anis, 'Inovasi dan Pemanfaatan teknologi Digital Bidang Kesehatan' (Presentation, Rakerkesnas, Tangerang, 12 February 2019)

Law

1945 constitution of the Republic of Indonesia

Law Number 40 year 2004 about National Social Security System (SJSN)

Law Number 24 year 2011 National Agency of Social Security System Organizer (Badan Penyelenggara Jaminan Sosial Nasional)

Law Number 17 year 2007 about National Long-term Development Plan

Minister of Health Regulation Number 20 year 2019 about Organizing Telemedicine Services Between Health Facilities Services

President Decree Number 82 year 2018 about Health Insurance 